\title{
Chemical composition and antioxidant activities of essential oils and extracts from cones of Tetraclinis articulata (Vahl) Masters
}

\author{
Mohammed Saber (iD)1, Hicham Harhar (D)1, Latifa El Hattabi (iD)1, Gokhan Zengin (iD)2, \\ Abdelhakim Bouyahya (D) 3,*, Mohamed Tabyaoui (D)1
}
${ }^{1}$ Laboratory of Materials, Nanotechnology \& Environment, Faculty of Sciences, Mohammed V University, Rabat, Morocco, Avenue Omar Ibn El Khattab, BP 763 Agdal, 14000, Rabat, Morocco
${ }^{2}$ Department of Biology, Science Faculty, Selcuk University, Konya, Turkey
${ }^{3}$ Laboratory of Human Pathologies Biology, Department of Biology, Faculty of Sciences, and Genomic Center of Human Pathologies, Faculty of Medicine and Pharmacy, Mohammed V University in Rabat, Morocco

\begin{abstract}
This study was carried out to evaluate the in vitro antioxidant activity and the chemical composition of essential oils and organic extracts of Moroccan Tetraclinis articulata cones (Khemisset region). The GC-MS analysis of essential oils identified a total 23 volatile components. The major constituents of the oil were $\alpha$-pinene $(18.33 \%)$, cis-verbenone $(10.02 \%)$, and L-pinocarveol (8. 32\%). For phytosterols analysis of hexane extract, $\beta$ sitosterol constitutes the majority with a percentage of $77.74 \%$. The amount of total phenolic and flavonoid contents was high in the methanol extract (78.54 $\pm 2.8 \mathrm{mg}$ GAE / $\mathrm{g}$ and $41.11 \pm 4.5 \mathrm{mg} \mathrm{QE} / \mathrm{g}$, respectively) and the Antioxidant capacity determined by DPPH method showed a strongest radical scavenging activity exhibition by the methanol extract (IC50 $=0.038 \pm 0.006$ $\mathrm{mg} / \mathrm{mL}$ ). The results indicated that $T$. articulata contains bioactive compounds which are responsible for its antioxidant activity. Therefore, this plant could be potential candidates for the preparation of a natural antioxidant drug or an additive preparation.
\end{abstract}

\section{ARTICLE HISTORY}

Received: Sep. 05, 2021

Revised: Oct. 16, 2021

Accepted: Nov. 06, 2021

\section{KEYWORDS}

Tetraclinis articulata,

Cones,

Essential oils,

Sterols,

Antioxidant activity.

\section{INTRODUCTION}

Reactive oxygen species (ROS) include species, such as the hydroxyl radical $(\cdot \mathrm{OH})$, hydrogen peroxide $\left(\mathrm{H}_{2} \mathrm{O}_{2}\right)$, and superoxide $\left(\mathrm{O}_{2}^{-}\right)$readily react with most biological macromolecules and leads to their oxidative modification and consequently resulting in the loss of their activities (Kapoor et al., 2019). They have the ability, to damage all biomolecules, causing peroxidation of lipids, oxidation of proteins, and damage to nucleic acids, enzyme inhibition (Madkour, 2020) which causes chemical alterations of these molecules (Mitra, 2020) leading to many chronic diseases such as pulmonary diseases (Park et al., 2006), cancer (Sosa et al., 2013), renal

\footnotetext{
*CONTACT: Gokhan Zengin $\bigotimes$ gokhanzengin@selcuk.edu.tr Department of Biology, Science Faculty, Selcuk University, Konya, Turkey

Abdelhakim Bouyahya $\square$ boyahyaa-90@hotmail.fr $\equiv$ Laboratory of Human Pathologies Biology, Department of Biology, Faculty of Sciences, and Genomic Center of Human Pathologies, Faculty of Medicine and Pharmacy, Mohammed V University in Rabat, Morocco
} 
diseases (Massy \& Nguyen-Khoa, 2002), neurodegenerative disorders (Uttara et al., 2009), metabolic and cardiovascular diseases (Incalza et al., 2018).

Synthetic phenolic antioxidants (SPAs) such as butylated hydroxyanisole (BHA), butylated hydroxytoluene (BHT), tertiary butyl hydroquinone (TBHQ), and propyl gallate (PG) are closely correlated with human life due to their extensive usages, and increasing concerns have been raised on their biosafety (Liu \& Mabury, 2020). Previous studies have found that some synthetic antioxidants and related transformation products showed toxicity effects including hepatic toxicity, endocrine disrupting effects, and even carcinogenicity (Yang et al., 2018; Dassarma et al., 2018). Recently there has been a considerable interest in finding natural antioxidants from natural resources such as medicinal plants to replace synthetic ones and to find more information concerning the antioxidant potential of plant (Jamshidi-kia et al., 2020).

In searching for novel natural antioxidants, The Thuya of Berber, Tetraclinis articulata (Vahl) Masters, known byits name "El ârâr" in Arabic, belongs to Cupressaceae family, is an endemic species to North Africa and in particular to the Maghreb countries (Morocco, Algeria and Tunisia). It is also found in some very specific areas, in the south-east of Spain (region of Almeria) and on the island of Malta (Kouider \& Assia, 2017). In addition, this forest species has an important sociological and economical role (Tsouli Faroukh et al., 2017).It is also widely used in traditional medicine because of its multiple therapeutic effects. Indeed, different parts of Thuya are recommended in the treatment of intestinal infections, gastric pain, respiratory diseases, diabetes, severe diarrhea, hypertension, and fever (Teixidor-Toneu et al., 2017; Hind et al., 2017). These uses reveal that extracts and essential oils of $T$. articulata contain compounds which exert numerous biological activities such as antibacterial, antioxidant, immunostimulatory, antifungic, anti-inflammatory, cytotoxic properties, anticholinesterase, anti-tyrosinase, antidiarrheal, and anti-ulcerative activities (Sadiki et al., 2019; Rabib et al., 2020; El-Shemy, 2020; Rached et al., 2018; Fidah et al., 2016; Jlizi et al., 2018; CalderónMontaño et al., 2018; Daoudi et al., 2013; Ababsa et al., 2019; Saber et al., 2021). The objective of this work is the evaluation of antioxidant activity and chemical characteristics of the essential oil and the extracts of the cones of Tetraclinis articulata from Khemisset.

\section{MATERIAL and METHODS}

\subsection{Plant collection and preparation}

The cones were harvested in March 2017 from Khemisset region and dried in the open air, at room temperature and protected from humidity. All measurements are performed in triplicate.

\subsubsection{Preparation of essential oil (EO)}

The extraction of essential oils was carried out by hydrodistillation in a Clevenger type apparatus (Clevenger, 1928). Briefly, 100g of the dry plant is placed in a balloon filled to $2 / 3$ with water; the whole is brought to the boil for 6 hours. The oil is recovered and then stored at a temperature of $4{ }^{\circ} \mathrm{C}$ for the tests.

\subsubsection{Preparation of extracts}

Firstly, $40 \mathrm{~g}$ of crushed Thuya cones are taken then put it in a cartridge before extracting it using a solvent (hexane, methanol) using the Soxhlet as an extraction material (Jensen, 2007). The system is heated at reflux for 6 hours, until discoloration. Samples are prepared by two different solvents used a successive extraction: hexane (for delipidation) then with methanol. The extracts obtained are evaporated to dryness using a rotary evaporator equipped with a vacuum pump and then stored at $4{ }^{\circ} \mathrm{C}$ for the tests.

\subsection{Phytochemical screening}

Chemical assays for screening and identification of bioactive constituents in T. articulata cones were performed with extracts prepared by qualitative characterization reactions. 


\subsubsection{Flavonoid detection}

Briefly, $1 \mathrm{~mL}$ of extract with a few drops of concentrated $\mathrm{HCl}$, and then adds a few milligrams of magnesium turnings. The presence of flavonoids is confirmed by the appearance of a pink to red orange color (N'Guessan et al., 2009).

\subsubsection{Alkaloid detection}

$100 \mathrm{mg}$ of extract with $3 \mathrm{ml} \mathrm{H}_{2} \mathrm{SO}_{4}(1 \%)$, the whole is brought to a boil in a water bath at 100 ${ }^{\circ} \mathrm{C}$ for $5 \mathrm{~min}$. After cooling and filtration, 5 drops of Mayer's reagent are added. The formation of a white precipitate indicates the presence of alkaloids (Mojab et al., 2010).

\subsubsection{Tannin detection}

The extract dissolved in distilled water and added drops of a solution of $\mathrm{FeCl}_{3}(1 \%)$. The appearance of a blue-black color indicates the presence of gallic tannins and the appearance of a green-blackish color indicates the presence of catechetical tannins (Y et al., 2004).

\subsubsection{Saponosides detection}

Mix $1 \mathrm{ml}$ of the extract with $2 \mathrm{~mL}$ of hot distilled water and stir for 15 seconds then let stand for $10 \mathrm{~min}$. A height of persistent foam, greater than $1 \mathrm{~cm}$ indicates the presence of Saponosides (Bekro et al., 2016).

\subsubsection{Sterols and polyterpenes detection}

The extract is diluted in $2 \mathrm{~mL}$ of acetic anhydride. The addition of a few drops of concentrated $\mathrm{H}_{2} \mathrm{SO}_{4}$ allows the appearance of a violet color which indicates the presence of sterols and polyterpenes (N'Guessan et al., 2009).

\subsection{Determination of the total phenolic content}

The determination of the total polyphenols of the methanol extract is carried out by the FolinCiocalteu method (Singleton et al., 1999). Briefly, $200 \mu \mathrm{L}$ of extract or reference (Gallic acid) with $800 \mu \mathrm{l}$ of the $\mathrm{Na}_{2} \mathrm{CO}_{3}$ solution (7.5\%), After stirring ( $5 \mathrm{~min}$ ), $1 \mathrm{~mL}$ of the Folin-Ciocalteu solution (diluted with distilled water 1:10) is added to the whole, after 2 hours of incubation at room temperature, the absorbance is read at $765 \mathrm{~nm}$ against a blank without extract. The results are expressed in micrograms of Gallic acid equivalent per milligram of extract ( $\mu \mathrm{g}$ EAG / mg of extract).

\subsection{Determination of flavonoids content}

The determination of flavonoids in our experiments is carried out by the method (QuettierDeleu et al., 2000). In test tubes $1 \mathrm{~mL}$ of methanol extract or standard (quercitin) and $1 \mathrm{~mL}$ of methanol solution of aluminum chloride (2\%). After $15 \mathrm{~min}$ of incubation at room temperature, the absorbances are read using a UV spectrophotometer visible at $430 \mathrm{~nm}$ against a blank (methanol added to $\mathrm{AlCl}_{3}$ ). The results are expressed in $\mu \mathrm{g}$ Quercetin equivalent per milligram of extract ( $\mu \mathrm{g}$ EQ / mg of extract).

\subsection{Analysis of Essential oil}

The gas chromatography/mass spectrometry (GC/MS) device is made by Perkin Elmer ClarusTM GC-680 with Q-8 MS. It is equipped with an auto-sampler, which gives access to the automatic injection of samples into the injector and a capillary column type RxiR-5Sil MS traversed by Helium gas. The mass spectrometer is powered by a SMART electronic ionization source. This source can ionize and vaporize the different molecules as well as a quadrupole filter to separate the different ions in their $\mathrm{m} / \mathrm{z}$ ratio. The GC/MS system is computer-controlled with Turbomass (TM) software, which allows programming of analytical methods as well as qualitative and quantitative identification of detected species. The analysis parameters are as follows: analysis time: 2 hours, vector gas flow rate: $1 \mathrm{~mL} / \mathrm{min}$, ionization energy: $70 \mathrm{eV}$, 
injector temperature: $260^{\circ} \mathrm{C}$, oven temperature: $40{ }^{\circ} \mathrm{C}$ for 2 minutes, then rise from $10{ }^{\circ} \mathrm{C} / \mathrm{min}$ to $290{ }^{\circ} \mathrm{C}$, and the injected volume is $0.5 \mu \mathrm{L}$.

\subsection{Determination of the composition of sterols}

Sterol composition was quantified according to the (ISO 6799, 1991), standard method using capillary gas chromatography (CGC) on an apolar column (Chroma pack) $(30 \mathrm{~m} \times 0.32 \mathrm{~mm}, \mathrm{DI}$ : $0.25 \mu \mathrm{m}$, phase: CPSIL8CB). The Varian CP-3800 chromatograph is equipped with a divider injector type $1079\left(\mathrm{~T}: 300^{\circ} \mathrm{C}\right)$ and an FID $\left(\mathrm{T}: 300^{\circ} \mathrm{C}\right)$ and using helium as carrier gas (flow: 1.5 $\mathrm{mL} / \mathrm{min})$.

\subsection{Evaluation of antioxidant activity (DPPH test)}

The scanning activity of the DPPH radical is measured according to the protocol described by (Lopes-Lutz et al., 2008). A methanol solution of $0.3 \mathrm{mM}$ of DPPH is mixed with different concentrations of the samples from the cones of T. articulata $(0.0025 ; 0.005 ; 0.01 ; 0.025 ; 0.05$; $0.1 ; 0.25 ; 0.5 ; 1 ; 2 \mathrm{mg} / \mathrm{mL}$ ). In a test tube, $2.5 \mathrm{~mL}$ of samples and controls solution (Ascorbic acid, Gallic acid and Quercetin) are added to $1 \mathrm{~mL}$ of the methanol solution of DPPH, after incubation for $30 \mathrm{~min}$ in the dark and at room temperature, the absorbances are measured at $517 \mathrm{~nm}$ against a blank which contains pure methanol. The negative control is composed of 1 $\mathrm{mL}$ of the methanol solution with DPPH and $2.5 \mathrm{~mL}$ of methanol.

\section{RESULTS / FINDINGS}

\subsection{Yield}

Table 1 summarizes the results of the study of the yield of the essential oil and extracts of $T$. articulata cones collected in the Khemisset region.

Table 1. Yield obtained from the different samples.

\begin{tabular}{lc}
\hline Samples & Yields (\%) \\
\hline Essential Oil & $0.33 \pm 0.05$ \\
\hline Hexane extract & $2.46 \pm 0.20$ \\
\hline Methanol extract & $13.22 \pm 1.01$ \\
\hline
\end{tabular}

The yield of the methanol extract is higher than that of the hexane extract by the order of $13.22 \pm 1.01 \%$ and $2.46 \pm 0.20 \%$, respectively (Table 1 ). The yield of essential oils calculated after 6 hours of extraction from the dry plant material is $0.33 \pm 0.05 \%$. These results are close to $0.31 \%$ found by (Buhagiar et al., 2000), have studied the essential oils cones of a cultivated stand of T. articulata growing in Malta (spain). Different yields are present in the literature, especially in Algeria. It was reported that the EO yield extracted from fresh cones of $T$. articulata from the Hammam Melouane region was $0.80 \%$ and that of Tipazaregion was $1.60 \%$ (Chikhoune et al., 2013). Also, the EO yield collected in Ain-Defla region was of the order of $0.52 \%$ (Djouahri et al., 2014). This yield being lower than that obtained by the sawdust of our other study (2.19\%) (Saber et al., 2021).

\subsection{Phytochemical screening}

The flavonoids and saponosides test indicate the presence with a strongly positive amount, then the alkaloid test reveals the presence in methanol extract. For the sterols and polyterpenes test shows the absence of these in the methanol extract. Also, the tannins test shows the absence of catechetical tannins and gallic tannins as can be seen in Table 2. 
Table 2. Results of the phytochemical screening of the methanol extract of the cones studied.

\begin{tabular}{lcccccc}
\hline $\begin{array}{l}\text { Secondary } \\
\text { metabolites }\end{array}$ & Flavonoids & Saponosides & Alkaloids & $\begin{array}{l}\text { Sterols and } \\
\text { polyterpenes }\end{array}$ & $\begin{array}{l}\text { Catechetical } \\
\text { tannins }\end{array}$ & $\begin{array}{c}\text { Gallic } \\
\text { tannins }\end{array}$ \\
\hline $\begin{array}{l}\text { Methanol } \\
\text { extract }\end{array}$ & +++ & +++ & ++ & - & - & - \\
\hline
\end{tabular}

(+++): Strongly positive test

$(++)$ : Positive average test

$(+)$ : Low positive test

(-): Negative test

The presence of flavonoids and saponosides in our extract is probably responsible for the free radical scavenging effects observed. Indeed, flavonoids are phenolic compounds inplant medicinal which recognized by their antioxidant potentials (Ait Lahcen et al., 2020). Also, saponosides have a wide range of pharmacological activities, including expectorant, antiinflammatory, vasoprotective, gastroprotective and antimicrobial properties (Koczurkiewicz et al., 2015). For Alkaloids they have shown to exert a broad spectrum of antimicrobial, anticancerogenic, and antimutagenic activity (Račková et al., 2004).

\subsection{Total phenolic and flavonoid content}

The content of phenolic compounds in two extracts was determined from the calibration curve for gallic acid and the results are expressed in $\mu \mathrm{g}$ gallic acid equivalent per mg of extract ( $\mu \mathrm{g}$ $\mathrm{EAG} / \mathrm{mg}$ ). On the other hand, the flavonoid content is expressed in $\mu \mathrm{g}$ quercetin equivalent per milligram of extract ( $\mu \mathrm{g}$ EQ / mg of extract). The calibration curves are shown in Figure 1. Based on these results, the methanol extract showed high phenolic and flavonoid compounds (78.54 $\pm 2.8 \mu \mathrm{g}$ GAE/mg and 41.11 $\pm 4.5 \mu \mathrm{g}$ QE/mg,respectively).

Figure 1. Gallic acid (phenolic) and quercetin (flavonoid) calibration curves.
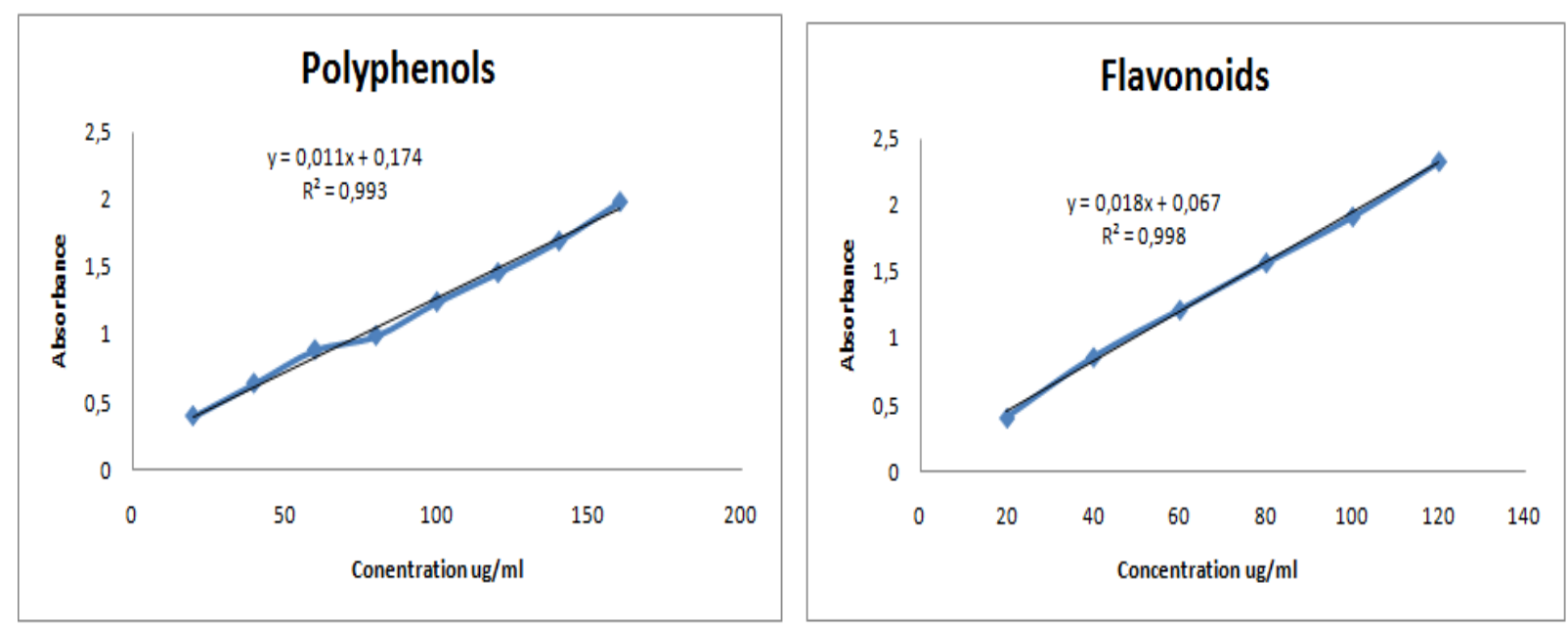

\subsection{Chemical compounds of Essential oils}

The GC-MS analysis of cones TAEO revealed the presence of 23 volatile compounds, the compounds identified are reported in Table 3. These compounds are belonging to different classes, including oxygenated monoterpenes (52.44\%) and hydrocarbons monoterpene $(27.78 \%)$. From these results, we note that this EO is mainly made up of $\alpha$-pinene $(18.33 \%)$, cis-Verbenone $(10.02 \%)$, L-pinocarveol (8.32\%), bicyclo[4.1.0]hept-2-ene $(6.76 \%), \alpha-$ campholenal $(6.10 \%)$, and D-limonene (5.75\%). To our knowledge, this study is the first carried 
out in Morocco, no study has been mentioned in the literature on the chemical composition of the Moroccan T. articulata cones.

Table 3. Chemical composition of the essential oil of T. articulata cones.

\begin{tabular}{|c|c|c|}
\hline Compounds & RT & $\%$ \\
\hline$\alpha$-pinene & 4.033 & 18.33 \\
\hline 2,4-thujadiene & 4.325 & 1.99 \\
\hline p-Xylene & 5.045 & 0.66 \\
\hline o-cymene & 5.347 & 1.71 \\
\hline D-limonene & 5.410 & 5.75 \\
\hline Styrene, 2,5-dimethyl- & 3.353 & 2.11 \\
\hline Linalool & 6.474 & 0.85 \\
\hline$\alpha$-campholenal & 6.940 & 6.10 \\
\hline L-Pinocarveol & 7.168 & 8.32 \\
\hline Cis-verbenol & 7.232 & 2.96 \\
\hline 3-Methylenecyclohexene & 7.301 & 3.18 \\
\hline D-Pinocamphone & 7.502 & 2.15 \\
\hline Bicyclo[4.1.0]hept-2-ene & 7.571 & 6.76 \\
\hline Terpinen-4-ol & 7.745 & 1.26 \\
\hline Thymol & 7.846 & 2.53 \\
\hline$\alpha$-terpineol & 7.941 & 1.60 \\
\hline Myrtenal & 8.052 & 5.22 \\
\hline cis-Verbenone & 8.259 & 10.02 \\
\hline trans-2-Caren-4-ol & 8.360 & 5.01 \\
\hline cis-Carveol & 8.540 & 0.94 \\
\hline D-Carvone & 8.757 & 2.62 \\
\hline Bornylacetate & 9.387 & 2.18 \\
\hline Terpinylacetate & 10.292 & 0.68 \\
\hline \multicolumn{2}{|c|}{ Monoterpenehydrocarbons } & 27.78 \\
\hline \multicolumn{2}{|c|}{ Oxygenatedmonoterpenes } & 52.44 \\
\hline \multicolumn{2}{|c|}{ Sesquiterpenehydrocarbons } & - \\
\hline \multicolumn{2}{|c|}{ Oxygenatedsesquiterpenes } & - \\
\hline \multicolumn{2}{|c|}{ Others } & 12.71 \\
\hline \multicolumn{2}{|c|}{ Total } & 92.93 \\
\hline
\end{tabular}

The comparative study carried out in the literature on $T$. articulata cones EOs reveal a homogeneity of major compounds. Indeed, Buhagiarand collaborators identified $\alpha$-pinene (68.2\%), limonene (16.6\%) (Buhagiar et al., 2000). Djouahri, who worked on T. articulata as an antimicrobial and anti-inflammatory plant, cited $\alpha$-campholenal $(16.34 \%)$; trans-pinocarveol (15.45\%); verbenone (13.36\%); cis-verbenol (12.36\%) (Djouahri et al., 2014). In another study (Chikhoune et al., 2013), Chikhoune et al. reported a chemical composition dominated by $\alpha$ pinene; $\beta$-myrcene; limonene for two EOs of the cones studied. These results are close to the results found by Boussaïd et al (Boussaïd et al., 2016) who examined the chemical composition of six EO of $T$. articulate cones collected in six different regions of Algeria with a quantitativedifference.

\subsection{Sterols compounds}

The sterols analyzed by CPG detected eight phytosterols for the hexane extract as summarized in Table 4. According to the results of Table 4, $\beta$-sitosterol constitutes the majority sterol with a percentage of $77.74 \%$, followed by $10.55 \%$ of compesterol; brassicasterol $(4.06 \%)$; stigmasterol (2.56\%); cholesterol $(0.48 \%) ; \Delta$-5-Avenosterol $(0.37 \%) ; \Delta$-7-Avenosterol $(0.27 \%)$ and $\Delta$-7-stigmasterol $(0.09 \%)$. 
Table 4. Chemical composition in sterols of hexane extract of Thuya cones.

\begin{tabular}{lc}
\hline Phytosterols & Pourcentage (\%) \\
\hline Cholesterol & 0.48 \\
\hline Brassicasterol & 4.06 \\
\hline Compesterol & 10.62 \\
\hline Stigmasterol & 2.56 \\
\hline$\beta$-Sitosterol & 77.21 \\
\hline$\Delta$-5-Avenosterol & 0.37 \\
\hline$\Delta$-7-Stigmasterol & 0.09 \\
\hline$\Delta$-7-Avenosterol & 0.27 \\
\hline
\end{tabular}

Among these, the most abundant phytosterols is $\beta$-sitosterol, which has a broad range of in vivo biological functions including antitumor, anti-inflammatory, antidiabetic, and gallstonereducing activities (Soleimanian et al., 2020).To our knowledge, this study is the first carried out on the composition of phytosterols, no study has been mentioned in the literature on the composition of phytosterols in T. articulata cones.

\subsection{Antioxidant activity of samples}

From Figure 2, it is quite clear that the percentages of neutralization of DPPH radical increase with increasing concentration of samples and standards (ascorbic acid, gallic acid and quercetin). The antioxidant activity is expressed in $\mathrm{IC}_{50}$, it defines the concentration of the extract or reference tested necessary to reduce $50 \%$ of the DPPH radical. In addition, the lower the $\mathrm{IC}_{50}$ values, the stronger the antioxidant power.

Figure 2. Evolution of the neutralization percentage (\%) for samples and standards.

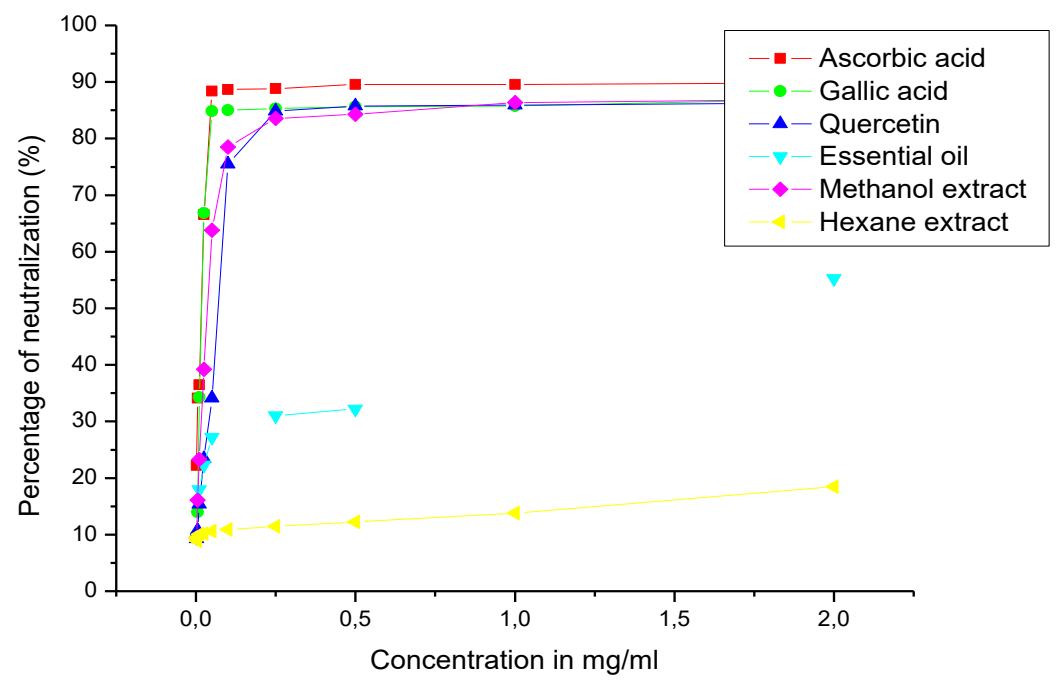

The concentrations which provide 50\% inhibition $\left(\mathrm{IC}_{50}\right)$ are grouped together in Table 5, where it is found that the IC50 values calculated for the methanol extract and references confirmed the reactivity of these samples with respect to DPPH. The results obtained demonstrated that the methanol extract $\left(\mathrm{IC}_{50}=0.038 \pm 0.006 \mathrm{mg} / \mathrm{mL}\right)$ has an antioxidant activity close to that of the standards and greater than the essential oils and hexane extract (absence) over the entire range of concentrations studied. 
Table 5. Antioxidant activity expressed in $\mathrm{IC}_{50}$.

\begin{tabular}{lc}
\hline & $\mathrm{IC}_{50}(\mathrm{mg} / \mathrm{mL})$ \\
\hline Ascorbic acid & $0.018 \pm 0.001$ \\
\hline Gallic acid & $0.020 \pm 0.003$ \\
\hline Quercetin & $0.070 \pm 0.004$ \\
\hline Essential oil & $1.677 \pm 0.026$ \\
\hline Methanol extract & $0.038 \pm 0.006$ \\
\hline Hexane extract & Absence \\
\hline
\end{tabular}

In comparison with the literature, the value of methanol extract obtained is higher than those obtained in the work carried out by Bensebia and collaborators $\left(\mathrm{IC}_{50}=0.14 \mathrm{mg} / \mathrm{ml}\right.$ ) were obtained from the T. articulata leaves extracted with $80 \%$ ethanol (Bensebia, s. d.). In addition, our essential oil shows better activity than two samples of essential oils from cones in two different sites in Algeria which showed low activity (Chikhoune et al., 2013).

\section{DISCUSSION and CONCLUSION}

The aromatic plants currently present a reliable source of active ingredients known for their therapeutic properties, in particular anti-oxidant activity. This work is interested in the study of the antioxidant activity of essential oil and organic extracts from the cones of $T$. articulata. The phytochemical tests carried out by the characterization reactions made it possible to highlight alkaloids, flavonoids and saponosides in the Thuya cones of the Khemisset region. The determination of phenolic compounds of methanol extract revealed considerable contents of polyphenols and flavonoids. Regarding antioxidant activity, we studied the antioxidant power through the capacity of DPPH radical scavenging, the methanol extract studied revealed a significant antioxidant potential. This study may find important application in the pharmaceutical and food industries.

\section{Declaration of Conflicting Interests and Ethics}

The authors declare no conflict of interest. This research study complies with research and publishing ethics. The scientific and legal responsibility for manuscripts published in IJSM belongs to the authors.

\section{Authorship Contribution Statement}

Mohammed Saber: Investigation, Resources, Visualization, Software, Formal Analysis, and Writing-original draft. Hicham Harhar: Methodology, Supervision, and Validation. Mohamed Tabyaoui: Methodology, Supervision, and Validation. Latifa El Hattabi: Visualization, Software and Formal Analysis. Gokhan Zengin: checked and corrected the final version. Abdelhakim Bouyahya: validation, checking and correction of the manuscript.

\section{Orcid}

Mohammed Saber (D) https://orcid.org/0000-0002-9121-5626

Hicham Harhar (id https://orcid.org/0000-0001-8266-0130

Latifa El Hattabi iD https://orcid.org/0000-0002-4606-8743

Gokhan Zengin (D) https://orcid.org/0000-0001-6548-7823

Abdelhakim Bouyahya (D) https://orcid.org/0000-0001-9317-1631

Mohamed Tabyaoui (iD https://orcid.org/0000-0001-6556-5238 


\section{REFERENCES}

Ababsa, Z. E. A., Derouiche, M. T., Medjroubi, K., \& Akkal, S. (2019). In-vivo Antidiarrhoeal and anti-ulcerative activities of the Tetraclinis articulata species of the Cupressaceae family. Acta Scientifica Naturalis, 6, 50-53. https://doi.org/10.2478/asn-2019-0007

Ait Lahcen, S., El Hattabi, L., Benkaddour, R., Chahboun, N., Ghanmi, M., Satrani, B., Tabyaoui, M., \& Zarrouk, A. (2020). Chemical composition, antioxidant, antimicrobial and antifungal activity of Moroccan Cistus Creticus leaves. Chemical Data Collections, 26, 100346. https://doi.org/10.1016/j.cdc.2020.100346

Bekro, Y.-A., Rosine, M., Allangba, A., Kadja, A., Guessennd, N., Kouadio, J., \& Janat Akhanovna, M.-B. (2016). Etude phytochimique bio-guidée, activités antibactérienne et analgésique de décoctions éthanoliques d'une Mimosaceae de Côte d'Ivoire [ Bio-guided phytochemical survey, antibacterial and analgesic activities of ethanolic decoctions of a Mimosaceae from Côte d'Ivoire ]. 18, 2028-9324.

Bensebia, B. (s. d.). Phytochemical analysis and assesment of antioxidant activity of Tetraclinis articulata (Vahl) Masters leaves. 1.

Boussaïd, M., Bekhechi, C., Atik-Bekkara, F., Paoli, M., Casanova, J., \& Tomi, F. (2016). Composition and Chemical Variability of the Cone Oil from Algerian Tetraclinis articulata. Natural Product Communications, 11(8), 1934578X1601100834. https://doi.org/10.1177/1 934578X1601100834

Buhagiar, J., Podestà, M. T. C., Cioni, P. L., Flamini, G., \& Morelli, I. (2000). Essential Oil Composition of Different Parts of Tetraclinis articulata. Journal of Essential Oil Research, 12(1), 29-32. https://doi.org/10.1080/10412905.2000.9712034

Calderón-Montaño, J. M., Martínez-Sánchez, S. M., Burgos-Morón, E., Guillén-Mancina, E., Jiménez-Alonso, J. J., García, F., Aparicio, A., \& López-Lázaro, M. (2018). Screening for Selective Anticancer Activity of 65 Extracts of Plants Collected in Western Andalusia, Spain. https://doi.org/10.20944/preprints201806.0177.v1

Chikhoune, A., Hazzit, M., Kerbouche, L., Baaliouamer, A., \& Aissat, K. (2013). Tetraclinis articulata (Vahl) Masters essential oils : Chemical composition and biological activities. Journal of Essential Oil Research, 25(4), 300-307. https://doi.org/10.1080/10412905.2013. 774625

Clevenger, J. F. (1928). Apparatus for the Determination of Volatile Oil*. The Journal of the American Pharmaceutical Association (1912), 17(4), 345-349. https://doi.org/10.1002/jps. $\underline{3080170407}$

Daoudi, A., Aarab, L., \& Abdel-Sattar, E. (2013). Screening of immunomodulatory activity of total and protein extracts of some Moroccan medicinal plants. Toxicology and Industrial Health, 29(3), 245-253. https://doi.org/10.1177/0748233711430972

Dassarma, B., Nandi, D. K., Gangopadhyay, S., \& Samanta, S. (2018). Hepatoprotective effect of food preservatives (butylated hydroxyanisole, butylated hydroxytoluene) on carbon tetrachloride-induced hepatotoxicity in rat. Toxicology Reports, 5, 31-37.https://doi.org/10. 1016/i.toxrep.2017.12.009

Djouahri, A., Saka, B., Boudarene, L., Benseradj, F., Aberrane, S., Aitmoussa, S., Chelghoum, C., Lamari, L., Sabaou, N., \& Baaliouamer, A. (2014). In vitro synergistic/antagonistic antibacterial and anti-inflammatory effect of various extracts/essential oil from cones of Tetraclinis articulata (Vahl) Masters with antibiotic and anti-inflammatory agents. Industrial Crops and Products, 56, 60-66. https://doi.org/10.1016/j.indcrop.2014.02.035

El-Shemy, H. (2020). Essential Oils : Oils of Nature. BoD - Books on Demand.

Fidah, A., Salhi, N., Janah, T., Rahouti, M., Kabouchi, B., El Alami, A., Ziani, M., \& Famiri, A. (2016). Comparative natural durability of four Mediterranean softwoods against wood decay fungi. Journal of the Indian Academy of Wood Science, 13(2), 132-137. https://doi.org/10.1007/s13196-016-0174-6 
Hind, S.-J., Anas, F., \& Lahcen, Z. (2017). Survey of Ethnomedicinal Plants Used for the Treatment of Gastrointestinal Disorders in Seksaoua Region (Western High Moroccan Atlas). Annual Research \& Review in Biology, 1-9. https://doi.org/10.9734/ARRB/2017/36 $\underline{112}$

Incalza, M. A., D’Oria, R., Natalicchio, A., Perrini, S., Laviola, L., \& Giorgino, F. (2018). Oxidative stress and reactive oxygen species in endothelial dysfunction associated with cardiovascular and metabolic diseases. Vascular Pharmacology, 100, 1-19. https://doi.org/10.1016/j.vph.2017.05.005

ISO 6799. (1991). Determination of the sterol fraction by gas chromatography.

Jamshidi-kia, F., Wibowo, J. P., Elachouri, M., Masumi, R., Salehifard-Jouneghani, A., Abolhasanzadeh, Z., \& Lorigooini, Z. (2020). Battle between plants as antioxidants with free radicals in human body. Journal of Herbmed Pharmacology, 9(3), 191-199.

Jensen, W. B. (2007, décembre 1). The Origin of the Soxhlet Extractor (world) [Researcharticle]. ACS Publications; Division of Chemical Education. https://doi.org/10.1021/ed084 p1913

Jlizi, S., Zardi-Bergaoui, A., Znati, M., Flamini, G., Ascrizzi, R., \& Ben Jannet, H. (2018). Chemical composition and biological evaluation of the resin from Tetraclinis articulata (Vahl.) Masters : A promising source of bioactive secondary metabolites. Industrial Crops and Products, 124, 74-83. https://doi.org/10.1016/j.indcrop.2018.07.055

Kapoor, D., Singh, S., Kumar, V., Romero, R., Prasad, R., \& Singh, J. (2019). Antioxidant enzymes regulation in plants in reference to reactive oxygen species (ROS) and reactive nitrogen species (RNS). Plant Gene, 19, 100182. https://doi.org/10.1016/j.plgene.2019.100 $\underline{182}$

Karumi, Y., Onyeyili, P.A., \& Ogugbuaja, V.O, (2004). Identification of Active Principles of M. balsamina (Balsam Apple) Leaf Extract. Journal of Medical Sciences, 4. https://doi.org/ 10.3923/jms.2004.179.182

Koczurkiewicz, P., Czyż, J., Podolak, I., Wójcik, K., Galanty, A., Janeczko, Z., \& Michalik, M. (2015). Multidirectional effects of triterpene saponins on cancer cells-Mini-review of in vitro studies. Acta Biochimica Polonica, 62(3), Article 3. https://ojs.ptbioch.edu.pl/index.p $\underline{\mathrm{hp} / \mathrm{abp} / \mathrm{article} / \mathrm{view} / 1740}$

Kouider, H., \& Assia, L. (2017). Synthèse bibliographique sur le thuya de berbérie [Tetraclinis articulata (Vahl) Mast.]. Geo-Eco-Trop, 41, 13-27.

Liu, R., \& Mabury, S. A. (2020). Synthetic Phenolic Antioxidants : A Review of Environmental Occurrence, Fate, Human Exposure, and Toxicity. Environmental Science \& Technology, 54(19), 11706-11719. https://doi.org/10.1021/acs.est.0c05077

Lopes-Lutz, D., Alviano, D. S., Alviano, C. S., \& Kolodziejczyk, P. P. (2008). Screening of chemical composition, antimicrobial and antioxidant activities of Artemisia essential oils. Phytochemistry, 69(8), 1732-1738. https://doi.org/10.1016/j.phytochem.2008.02.014

Madkour, L. H. (2020). RETRACTED CHAPTER : Sources of Oxidants and Function of ROS Inside the Macromolecule Cells. In L. H. Madkour (Éd.), RETRACTED BOOK Nanoparticles Induce Oxidative and Endoplasmic Reticulum Stresses: Antioxidant Therapeutic Defenses (p. 99-138). Springer International Publishing. https://doi.org/10.100 7/978-3-030-37297-2 3

Massy, Z. A., \& Nguyen-Khoa, T. (2002). Oxidative stress and chronic renal failure : Markers and management. Journal of Nephrology, 15(4), 336-341.

Mitra, A. K. (2020). Antioxidants : A Masterpiece of Mother Nature to Prevent Illness. Journal of Chemical Reviews, 2(4), 243-256. https://doi.org/10.22034/jcr.2020.112730

Mojab, F., Kamalinejad, M., Ghaderi, N., \& Vahidipour, H. R. (2010). Phytochemical Screening of Some Species of Iranian Plants. Iranian Journal of Pharmaceutical Research, 0 (Number 2), 77-82. https://doi.org/10.22037/ijpr.2010.16 
N’Guessan, K., Kadja, B., Zirihi, G., Traoré, D., \& Aké-Assi, L. (2009). Screening phytochimique de quelques plantes médicinales ivoiriennes utilisées en pays Krobou (Agboville, Côte-d'Ivoire). Sciences \& Nature, 6(1), Article 1. https://doi.org/10.4314/scin at.v6i1.48575

Park, H. S., Chun, J. N., Jung, H. Y., Choi, C., \& Bae, Y. S. (2006). Role of NADPH oxidase 4 in lipopolysaccharide-induced proinflammatory responses by human aortic endothelial cells. Cardiovascular Research, 72(3), 447-455. https://doi.org/10.1016/j.cardiores.2006.0 $\underline{9.012}$

Quettier-Deleu, C., Gressier, B., Vasseur, J., Dine, T., Brunet, C., Luyckx, M., Cazin, M., Cazin, J.-C., Bailleul, F., \& Trotin, F. (2000). Phenolic compounds and antioxidant activities of buckwheat (Fagopyrum esculentum Moench) hulls and flour. Journal of Ethnopharmacology, 72(1), 35-42. https://doi.org/10.1016/S0378-8741(00)00196-3

Rabib, H., Elagdi, C., Hsaine, M., Fougrach, H., Koussa, T., \& Badri, W. (2020). Antioxidant and Antibacterial Activities of the Essential Oil of Moroccan Tetraclinis articulata (Vahl) Masters. Biochemistry Research International, 2020, e9638548. https://doi.org/10.1155/20 20/9638548

Rached, W., Zeghada, F. Z., Bennaceur, M., Barros, L., Calhelha, R. C., Heleno, S., Alves, M. J., Carvalho, A. M., Marouf, A., \& Ferreira, I. C. F. R. (2018). Phytochemical analysis and assessment of antioxidant, antimicrobial, anti-inflammatory and cytotoxic properties of Tetraclinis articulata (Vahl) Masters leaves. Industrial Crops and Products, 112, 460-466. https://doi.org/10.1016/j.indcrop.2017.12.037

Račková, L., Májeková, M., Košt’álová, D., \& Štefek, M. (2004). Antiradical and antioxidant activities of alkaloids isolated from Mahonia aquifolium. Structural aspects. Bioorganic \& Medicinal Chemistry, 12(17), 4709-4715. https://doi.org/10.1016/j.bmc.2004.06.035

Saber, M., Hicham, H., Bouyahya, A., Ouchbani, T., \& Tabyaoui, M. (2021). Chemical Composition and Antioxidant Activity of Essential Oil of Sawdust from Moroccan Thuya (Tetraclinis articulata (Vahl) Masters. Biointerface Research in Applied Chemistry, 11, 7912-7920. https://doi.org/10.33263/BRIAC111.79127920

Sadiki, F. Z., Idrissi, M. E., Cioanca, O., Trifan, A., Hancianu, M., Hritcu, L., \& Postu, P. A. (2019). Tetraclinis articulata essential oil mitigates cognitive deficits and brain oxidative stress in an Alzheimer's disease amyloidosis model. Phytomedicine, 56, 57-63. https://doi.org/10.1016/j.phymed.2018.10.032

Singleton, V. L., Orthofer, R., \& Lamuela-Raventós, R. M. (1999). [14] Analysis of total phenols and other oxidation substrates and antioxidants by means of folin-ciocalteu reagent. In Methods in Enzymology (Vol. 299, p. 152-178). Academic Press. https://doi.org/10.1016 /S0076-6879(99)99017-1

Soleimanian, Y., Goli, S. A. H., Varshosaz, J., Di Cesare Mannelli, L., Ghelardini, C., Cirri, M., \& Maestrelli, F. (2020). $\beta$-Sitosterol Loaded Nanostructured Lipid Carrier : Physical and Oxidative Stability, In Vitro Simulated Digestion and Hypocholesterolemic Activity. Pharmaceutics, 12(4), 386. https://doi.org/10.3390/pharmaceutics12040386

Sosa, V., Moliné, T., Somoza, R., Paciucci, R., Kondoh, H., \& LLeonart, M. E. (2013). Oxidative stress and cancer: An overview. Ageing Research Reviews, 12(1), 376-390. https://doi.org/10.1016/j.arr.2012.10.004

Teixidor-Toneu, I., Martin, G. J., Puri, R. K., Ouhammou, A., \& Hawkins, J. A. (2017). Treating infants with frigg: Linking disease aetiologies, medicinal plant use and careseeking behaviour in southern Morocco. Journal of Ethnobiology and Ethnomedicine, 13(1), 4. https://doi.org/10.1186/s13002-016-0129-4

Tsouli Faroukh, A., Tellal, R., \& Qarro, M. (2017). Analysis of socio-economic mutations in the Benslimane forest Lever for sustainable development (Province of Benslimane, 
Morocco. Journal of Materials and Environmental Sciences, 8(12), 4415-4425. https://doi.org/10.26872/jmes.2017.8.12.466

Uttara, B., Singh, A. V., Zamboni, P., \& Mahajan, R. T. (2009). Oxidative Stress and Neurodegenerative Diseases: A Review of Upstream and Downstream Antioxidant Therapeutic Options. Current Neuropharmacology, 7(1), 65-74.

Yang, X., Song, W., Liu, N., Sun, Z., Liu, R., Liu, Q. S., Zhou, Q., \& Jiang, G. (2018). Synthetic Phenolic Antioxidants Cause Perturbation in Steroidogenesis in Vitro and in Vivo. Environmental Science \& Technology, 52(2), 850-858. https://doi.org/10.1021/acs.est.7b05 $\underline{057}$ 